Proc. Estonian Acad. Sci. Geol., 2001, 50, 1, 51-65

\title{
SPREAD OF BROAD-LEAVED TREES IN ESTONIA
}

\author{
Leili SAARSE and Siim VESKI
}

Institute of Geology, Tallinn Technical University, Estonia pst. 7, 10143 Tallinn, Estonia; saarse@gi.ee,veski@gi.ee

Received 4 May 2000

\begin{abstract}
The spread of broad-leaved trees (Ulmus, Tilia, Quercus, Fraxinus, Carpinus, and Fagus) is reviewed on the basis of 46 radiocarbon dated pollen diagrams from lake and mire sediments from Estonia. Ulmus immigrated into Estonia in the second half of the Pre-Boreal, expanded between 9000 and $7800 \mathrm{BP}$, and reached its maximum values 7900-4200 BP. The immigration of Tilia began between 8800 and $6200 \mathrm{BP}$; it expanded at 8200-5200 BP, and culminated between 7200 and 4000 BP. Quercus was the next tree to arrive in Estonia, about 7900-7500 BP. Oak spread between 6800 and $4000 \mathrm{BP}$, with a maximum intermittent between 4200 and 3100 BP. Fraxinus was first recorded about $6500 \mathrm{BP}$ from East Estonia. Carpinus is a late immigrant which reached Estonia in the Sub-Boreal. Comparison of the immigration and expansion of elm, lime, and oak manifests their different response to climate, with elm forest being most broadly distributed between 9000 and $7000 \mathrm{BP}$, lime between 7000 and $4000 \mathrm{BP}$ (forming then up to 30\% of the total forest area), and oak between 4000 and $3500 \mathrm{BP}$. Elm showed a very rapid colonization from the south; the immigration of lime was more time-transgressive and took place from the south and east. Oak immigrated from the southwest and, in contrast to elm, spread very slowly. The broad-leaved forest reached its maximum density in the second half of the Atlantic and at the beginning of the Sub-Boreal. A gradual retreat of thermophilous trees started with the elm decline at about 5500 $5000 \mathrm{BP}$, which was quite asynchronous, being caused by the combination of climate deterioration, anthropogenic forest clearances, and fungal diseases.
\end{abstract}

Key words: Ulmus, Tilia, Quercus, Fraxinus, Carpinus, Fagus, pollen, immigration, Holocene, Estonia.

\section{INTRODUCTION}

About 400 pollen diagrams covering the Holocene completely or partially are available from Estonia. Only 46 diagrams are supported by at least three radiocarbon dates. It is a rather complicated task to synthesize such an archive of pollen data, because the diagrams originate from various landscape types, lakes and mires of different size, and from the material analysed over a long time and at different levels. One of the issues of this work is to map the immigration and expansion of different tree taxa and obtain information on vegetation patterns. Isopoll and isochrone maps have been widely adopted, because they provide a visual summary of palynological data (Huntley 1988; Birks 1989). However, several 
sources of error, such as the pollen sum, long-distance transport (Tallantire 1972), and the size of the basin (Davis \& Sugita 1997) affect the validity of these maps. Huntley \& Birks (1983) compiled the isopoll maps of trees for Europe, and Serebryannyi (1973) presented the isochrone maps for the northwestern part of the former Soviet Union, including Estonia. Huntley (1988) has also indicated certain immigration routes and rate ranges of major tree taxa. The latest investigations of macrofossils from the Scandes Mountains have shown that thermophilous broadleaved trees arrived there considerably earlier than has been concluded on the basis of microfossil (pollen) records (Kullmann 1998). Yet, such records are not available from Estonia.

Based on 46 pollen profiles, of which 23 are analysed with high temporal and taxonic resolution, we would like to highlight the immigration patterns and revise the rate range of broad-leaved taxa in Estonia. We also present new isopoll maps at 500-year series for the Holocene of Estonia and discuss the declines of Ulmus and Tilia.

\section{FOREST COVER}

Estonia belongs to the northern part of the mixed conifer-hardwood zone, where the main forest-forming tree in present-day vegetation is Pinus sylvestris $(41 \%)$, followed by Betula pendula and B. pubescens (28\%), Picea abies (23\%), Alnus incana (4\%), Populus tremula (2\%), and broad-leaved trees (1\%; Külvik 1996). The total proportion of woods dominated by deciduous trees is $37 \%$. At present there are two native Ulmus (elm) species in Estonia (Ulmus glabra Huds. and $U$. laevis Pall.), whereas the range limit of $U$. glabra lies more northerly, along the Estonian coastline, and the northern range of U. laevis crosses Estonia diagonally, roughly along the Pärnu-Narva line (Kaar 1974). Both species of Ulmus are rather frost resistant, but demand fertile soils. Elm stands are scarce, occurring in protected locations in Sakala Upland valleys and in the sheltered foreklint mixed forest together with lime, maple, and ash. Single planted elm trees are common in farmyards. Tilia cordata Mill. (lime) also needs fertile soils, and its stands are rare, being present at Alutaguse (Northeast Estonia) and in the vicinity of Elva (South Estonia) (Paves 1974). Its northern limit lies in South Finland, and its eastern limit is farther than that of any other broad-leaved trees described here (Hultén 1950; Peterson 1983). Quercus robur L. (oak) is native in Estonian oak stands and its northern boundary lies here (Kalda 1972). Oak forests account for about $0.5 \%$ of the total forest area in Estonia (Kaar 1972b). Natural oak stands are rather common on fertile calcareous soils of West Estonia and Saaremaa Island. On the West Saaremaa Elevation oak grows mainly in the second layer under pine, in West Estonia it occurs on woody meadows, and in Central Estonia on fertile floodplains. The geographic range of the common ash (Fraxinus excelsior L.) extends a little farther to the north than that of Quercus, being here also close to its northern range limit (Kaar 1974). It is the only species of ash that grows naturally in Estonia, mainly on Saaremaa Island, West Estonia, and the Ugandi plateau around Tartu, missing almost entirely in the southeast (Kaar 1972a). It 
prefers to grow on moist, nutrient-rich soils in mixed forest, where it is in minority, forming $0.1 \%$ of the total forest area. Carpinus betulus L. (hornbeam) is not native in Estonia today, and the limit of its geographic range crosses Lithuania.

\section{MATERIAL AND METHODS}

Isopoll maps for Ulmus, Tilia, and Quercus were reconstructed for 500-year intervals to summarize the palaeobotanical record, those for Ulmus from $9800 \mathrm{BP}$, those for Tilia and Quercus from 8000 BP. Ulmus and Quercus are relatively good pollen producers (Andersen 1970), and their rational pollen limit was used to establish their spread. For Tilia the empirical limit was used for the same purpose. However, this does not exclude the possibility that the first arrival of these trees occurred earlier. Forty-five sites with 46 pollen diagrams, all compiled after 1967 and provided with radiocarbon dates, served as the basis for the present study (Table 1, Fig. 1). The diagrams used have a radiocarbon dated empirical

Table 1. List of sites with references, where the radiocarbon dates and pollen diagrams are given

\begin{tabular}{|c|c|c|c|c|c|}
\hline $\begin{array}{l}\text { Site and } \\
\text { No. on the map } \\
\text { (Fig. 1) }\end{array}$ & \begin{tabular}{|c|} 
No. of \\
${ }^{14} \mathrm{C}$ \\
dates
\end{tabular} & References & $\begin{array}{l}\text { Site and } \\
\text { No. on the map } \\
\text { (Fig. } 1)\end{array}$ & \begin{tabular}{|c|} 
No. of \\
${ }^{14} \mathrm{C}$ \\
dates
\end{tabular} & References \\
\hline 1. Kirikumäe & 10 & Saarse \& Rajamäe 1997 & 26. Viitna & 4 & Koff 1984 \\
\hline 2. Punso & 12 & Saarse \& Rajamäe 1997 & kettle hole & & \\
\hline 3. Remmeski & 12 & Sarv 1983 & 27. Viitna & 9 & Saarse et al. 1998 \\
\hline 4. Vaskna & 16 & Ilves \& Mäemets 1987 & Pikkjärv & & \\
\hline 5. Tuuljärv & 9 & Ilves \& Mäemets 1987 & 28. Kahala & 13 & Poska \& Saarse 1999 \\
\hline 6. Vällamäe & 12 & Punning et al. 1995 & 29. Maardu & 8 & Veski 1998 \\
\hline 7. Senno & 9 & Sarv 1983 & 30. Tondi & 3 & Kimmel et al. 1996 \\
\hline 8. Obtjok & 10 & Miidel et al. 1995 & 31. Vaharu & 10 & Sarv \& Ilves 1971 \\
\hline 9. Toolamaa & 13 & Kimmel et al. 1999 & 32. Mustjärv & 7 & Veski 1998 \\
\hline 10. Kalsa & 11 & Kimmel et al. 1999 & 33. Järveotsa & 4 & Poska 1994 \\
\hline 11. Kuiksilla & 9 & Ilves et al. 1967 & 34. Velise & 8 & Veski 1998 \\
\hline 12. Akali & 7 & Moora et al. 1988 & 35. Ermistu & 9 & Veski 1998 \\
\hline \multirow[t]{2}{*}{ 13. Saviku } & \multirow[t]{2}{*}{14} & Sarv \& Ilves 1975; & 36. Nigula 1 & 11 & Sarv \& Ilves 1976 \\
\hline & & Saarse et al. 1996 & 37. Nigula 2 & 14 & Sarv \& Ilves 1976 \\
\hline 14. Ulila & 13 & Ilves \& Sarv 1970 & 38. Mõksi & 6 & Sarv \& Ilves 1976 \\
\hline 15. Võrtsjärv & 9 & Pirrus et al. 1993 & 39. Järvesoo & 13 & Saarse 1994 \\
\hline 16. Päidre & 17 & Saarse et al. 1995 & 40. Pitkasoo & 7 & Königsson \& Poska \\
\hline \multirow[t]{2}{*}{ 17. Raigastvere } & 11 & Pirrus et al. 1987b; & & & 1998 \\
\hline & & Saarse et al. 1996 & 41. Karujärv & 10 & Saarse \& Königsson \\
\hline 18. Laiuse & 3 & Pirrus et al. 1987a & & & 1992 \\
\hline 19. Teosaare & 15 & Ilves et al. 1968 & 42. Vedruka & 12 & Poska \& Saarse 2001 \\
\hline 20. Linnusaare & 8 & Ilves 1980 & 43. Pelisoo & 7 & Saarse \& Königsson \\
\hline 21. Äntu & 7 & Saarse \& Liiva 1995 & & & 1992; Veski 1998 \\
\hline 22. Võhmajärve & 14 & Kimmel et al. 1999 & 44. Jõhvikasoo & 5 & Hansson et al. 1996 \\
\hline 23. Liivjärv & 6 & Koff 1994 & 45. Surusoo & 15 & Veski 1998; \\
\hline 24. Kalina & 12 & Ilves \& Sarv 1969 & & & Rasmussen et al. 2000 \\
\hline 25. Leekovo & 3 & Lepland et al. 1996 & 46. Kõivasoo & 8 & Königsson et al. 1998 \\
\hline
\end{tabular}




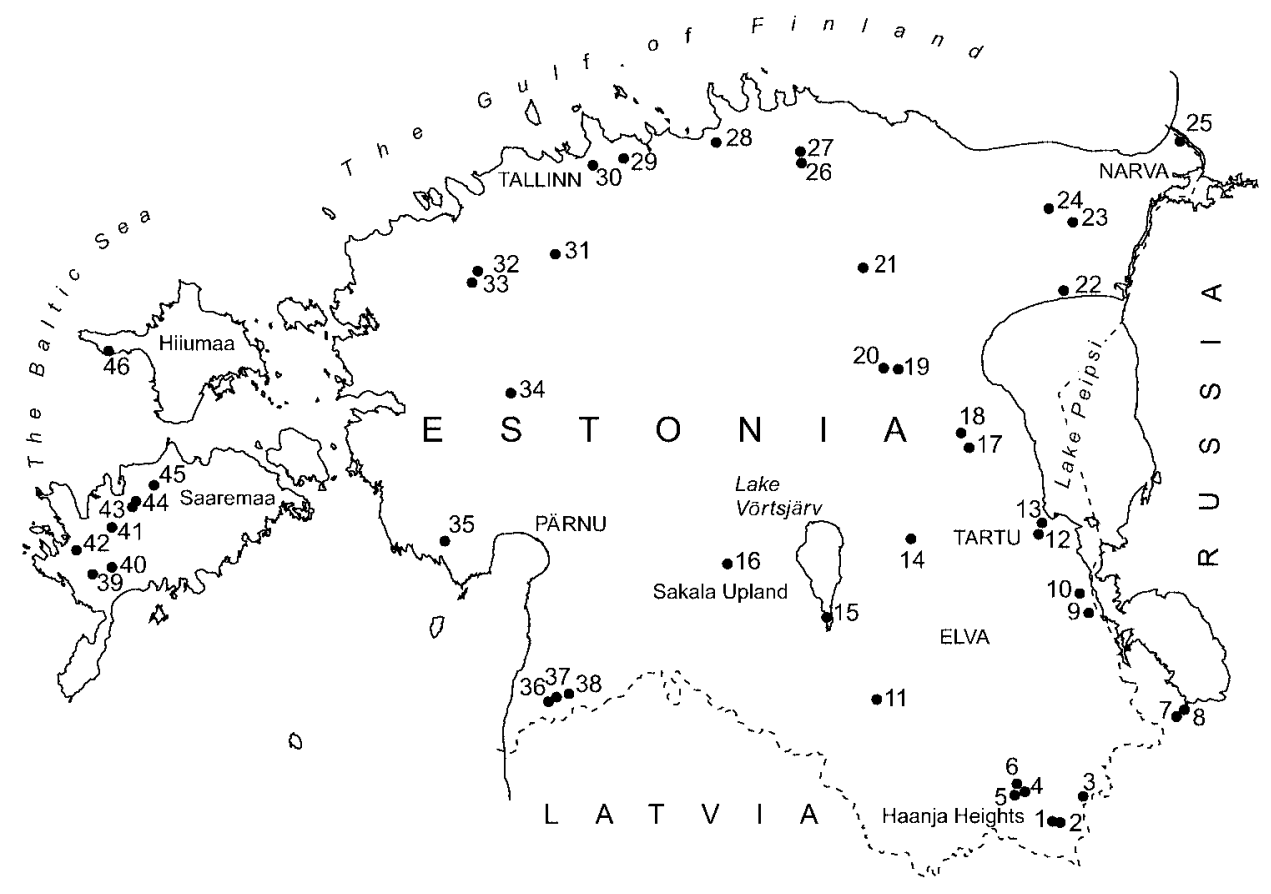

Fig. 1. Location of the examined biostratigraphical sites in Estonia. For the list of sites and references see Table 1.

limit (start of a continuous pollen curve), rational limit (rise of the curve), and the maximum pollen occurrence of the described taxa. If ${ }^{14} \mathrm{C}$ dates were absent, the ages of these events were interpolated. Radiocarbon dates quoted in the text are uncalibrated radiocarbon years before present (BP). As the ${ }^{14} \mathrm{C}$ dates originate from different materials, including lake deposits, the dates given here should be taken as broad approximations rather than precise estimates. Although the number of dated diagrams (46) and radiocarbon dates (445) is rather high, there are areas which still need well-dated pollen diagrams, such as the Sakala Upland and Central Estonia.

\section{RESULTS}

Ulmus immigrated into Estonia during the Pre-Boreal, and by the end of the chronozone its empirical limit was recorded in 13 and rational limit in 10 sites/diagrams, unevenly scattered over the studied area (Figs. 2a, 3). Ulmus spread rather rapidly. By $8000 \mathrm{BP}$ it surpassed the rational limit in more than half of the examined sites (Fig. 2b) and reached the 15\%-level at Raigastvere and Kahala (Pirrus et al. 1987b; Poska \& Saarse 1999). In contrast to the quick spread 

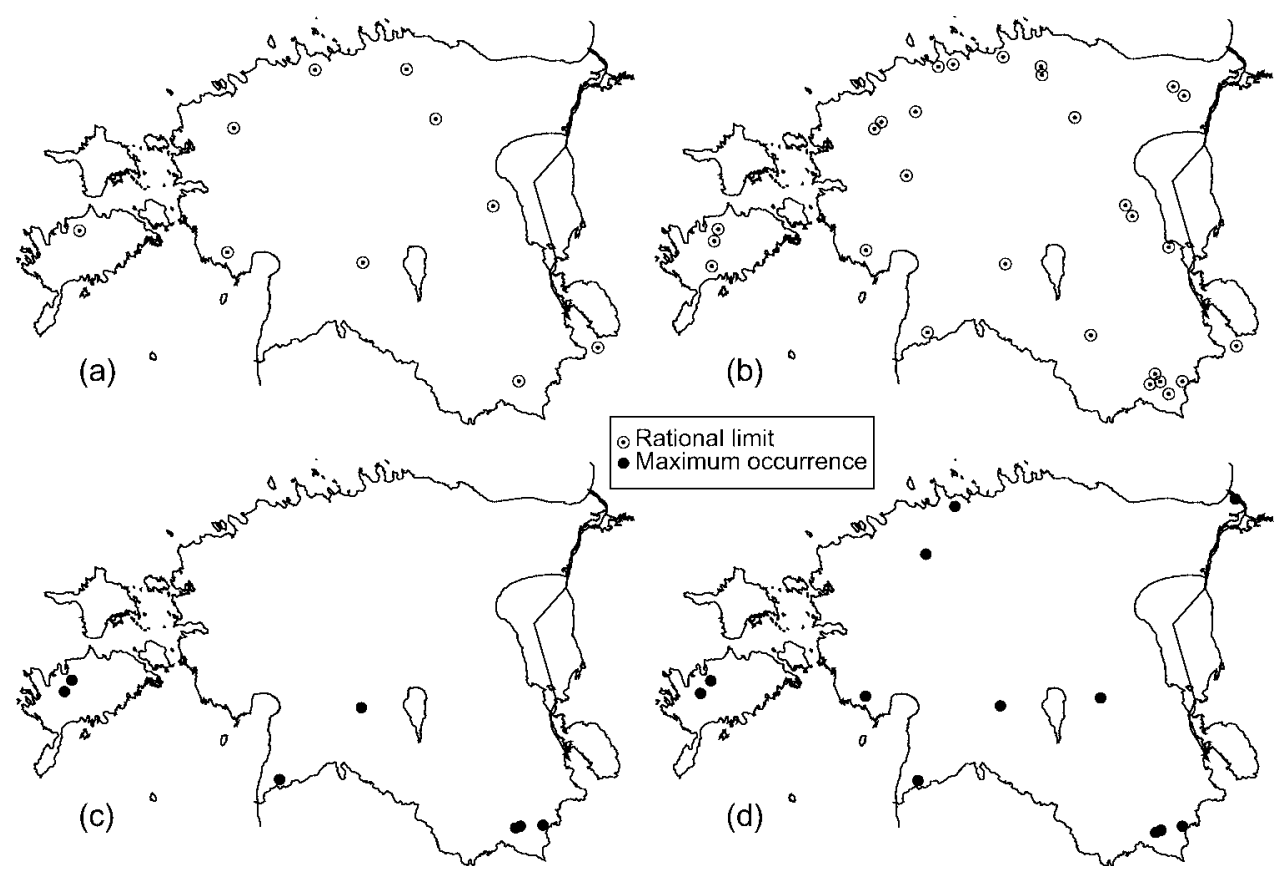

Fig. 2. Maps showing the distribution of Ulmus pollen at different times. (a) the rational limit before $9000 \mathrm{BP}$, (b) the rational limit between 8500 and $8000 \mathrm{BP}$, (c) maximum occurrence before $7000 \mathrm{BP}$, (d) maximum occurrence between 7000 and $6500 \mathrm{BP}$.

of Ulmus, its maximum occurrence is dispersed over more than 3500 years, between 7900 and $4200 \mathrm{BP}$, being still more or less well pronounced between 6500 and 5600 BP (Fig. 3). Ulmus reached its maximum first in South Estonia and Saaremaa (Fig. 2c), being in some places delayed due to the absence of favourable habitats. By $6500 \mathrm{BP}$ Ulmus had reached maximum values at 12 sites (Fig. 2d), and at $6000 \mathrm{BP}$ its maximum was recorded in 21 pollen profiles in different regions. At the end of the Atlantic Ulmus started to retreat, and by $5000 \mathrm{BP}$ its decline was recorded in 26 pollen diagrams. Ulmus pollen decreased throughout the Sub-Boreal and Sub-Atlantic, and by $1000 \mathrm{BP}$ its pollen frequencies became extinct or decreased below the rational limit. Ulmus is a minor pollen type within the northern limit also elsewhere around Estonia, and its modern pollen percentage is generally below 1 (Peterson 1983).

Tilia. Scattered finds of Tilia pollen have been registered before $8000 \mathrm{BP}$ at southern and eastern sites of Estonia (Fig. 4a). Like Ulmus, Tilia also expanded rather fast (Fig. 4b), and by $7000 \mathrm{BP}$ its empirical limit was recorded in 34 and rational limit in 19 pollen profiles (Figs. 3, 4c). At 7500 BP Tilia was missing in the pollen profiles of Northwest Estonia (Fig. 4b), where it reached during the next 500 years (Fig. 4c). The highest extent of Tilia pollen is recorded between 


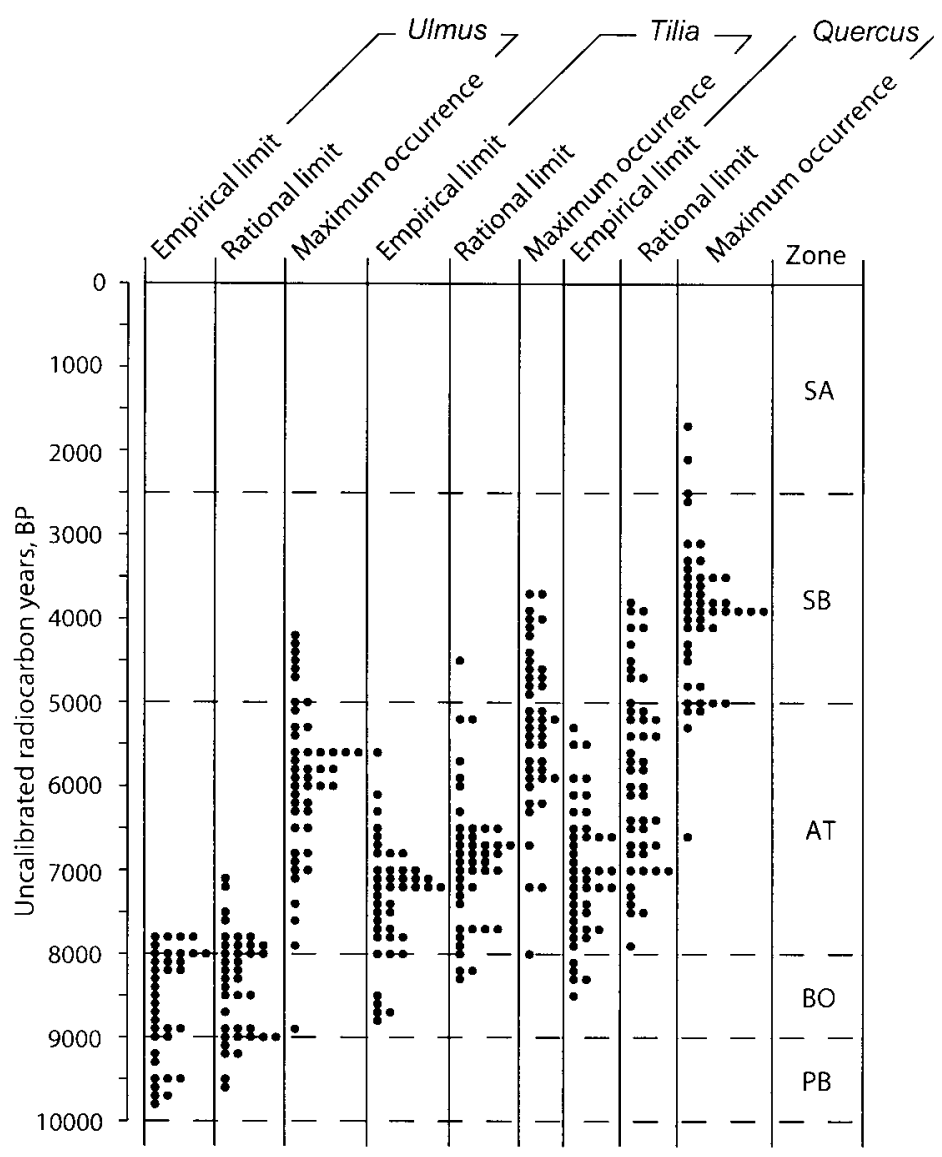

Fig. 3. Time-distribution of the empirical and rational limits of elm (Ulmus), lime (Tilia), and oak (Quercus) pollen and their maximum occurrence.

6300 and $4000 \mathrm{BP}$, first mostly at the sites it had reached first (Fig. 4d). After 5000 BP Tilia also started to decline. The decline was more pronounced between 4600 and 4500 and after 3600 BP. Only on the Haanja Heights Tilia pollen maintained high frequency up to $3000 \mathrm{BP}$. At most sites the representation of Tilia pollen gradually decreased; from $2000 \mathrm{BP}$ and during the last millennia its pollen is present only in very low values or has disappeared completely. At present the proportion of Tilia pollen exceeds the limit of $1 \%$ only at the deciduous forest sites, but occurs in minor quantities elsewhere in the mixed forest (Peterson 1983).

Quercus was the next tree to arrive at about 7900-7500 BP, when its rational limit was recorded at 3 and empirical limit at 14 sites (Fig. 3), which shows that oak remained rather rare at the beginning of the Atlantic. However, single 


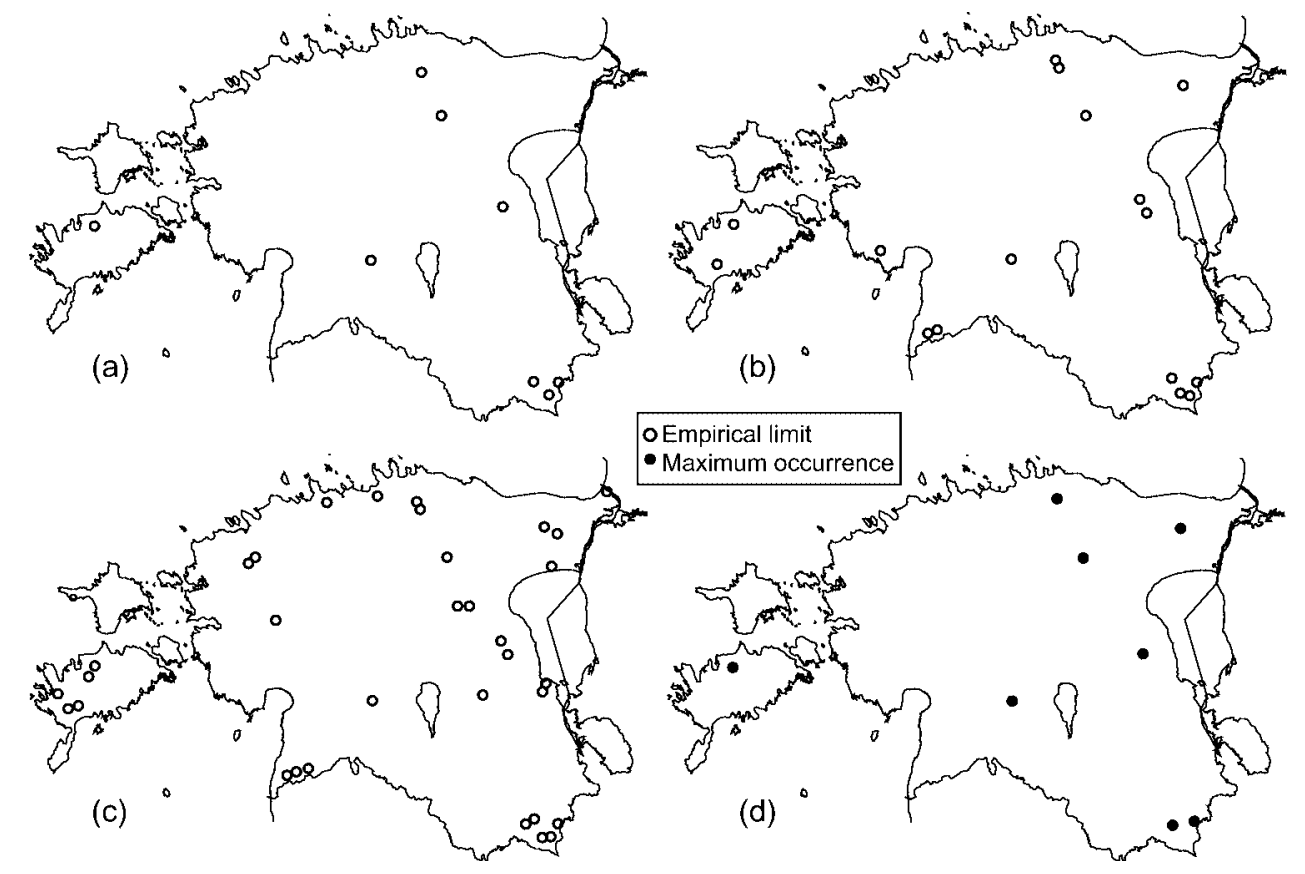

Fig. 4. Maps showing the distribution of Tilia pollen at different times. (a) the empirical limit before $8000 \mathrm{BP}$, (b) the empirical limit between 8000 and $7500 \mathrm{BP}$, (c) the empirical limit between 7500 and $7000 \mathrm{BP},(\mathrm{d})$ maximum occurrence between 6500 and $6000 \mathrm{BP}$.

Quercus trees could have been present earlier, before $8000 \mathrm{BP}$, because already at that time Quercus pollen forms a continuous curve at 5 sites. Quercus expanded slowly and by $7000 \mathrm{BP}$ it surpassed the empirical limit at 27 sites and the rational limit at 10 sites, being distributed unevenly over the studied area (Fig. 5a). A millennium later Quercus had reached its empirical limit at 40 sites and rational limit at 24 sites (Fig. 5b). The peak in Quercus appeared between 4200 and $3100 \mathrm{BP}$ when it attained its maximum extent (Fig. 5c,d), being delayed in the northwestern part of Estonia. The culmination phase of Quercus came to an end at about 3000 BP, when its main habitats were occupied by spruce (Saarse et al. 1999). Modern surface pollen data show that, unlike Ulmus and Tilia, Quercus pollen is present in low values at almost all examined sites.

Fraxinus record starts at $7500 \mathrm{BP}$ at several sites of Saaremaa and West Estonia and c. $6500 \mathrm{BP}$ in the eastern part of Estonia. The proportion of Fraxinus pollen is low, commonly 1-2\%, exceeding the 3\%-level at Mustjärve, Ermistu (Veski 1998), Kõivasoo (Königsson et al. 1998), and Viitna (Saarse et al. 1998) and the 5\%-level at Maardu (Veski 1998). Fraxinus started to decrease about $3500 \mathrm{BP}$, almost simultaneously with oak. 

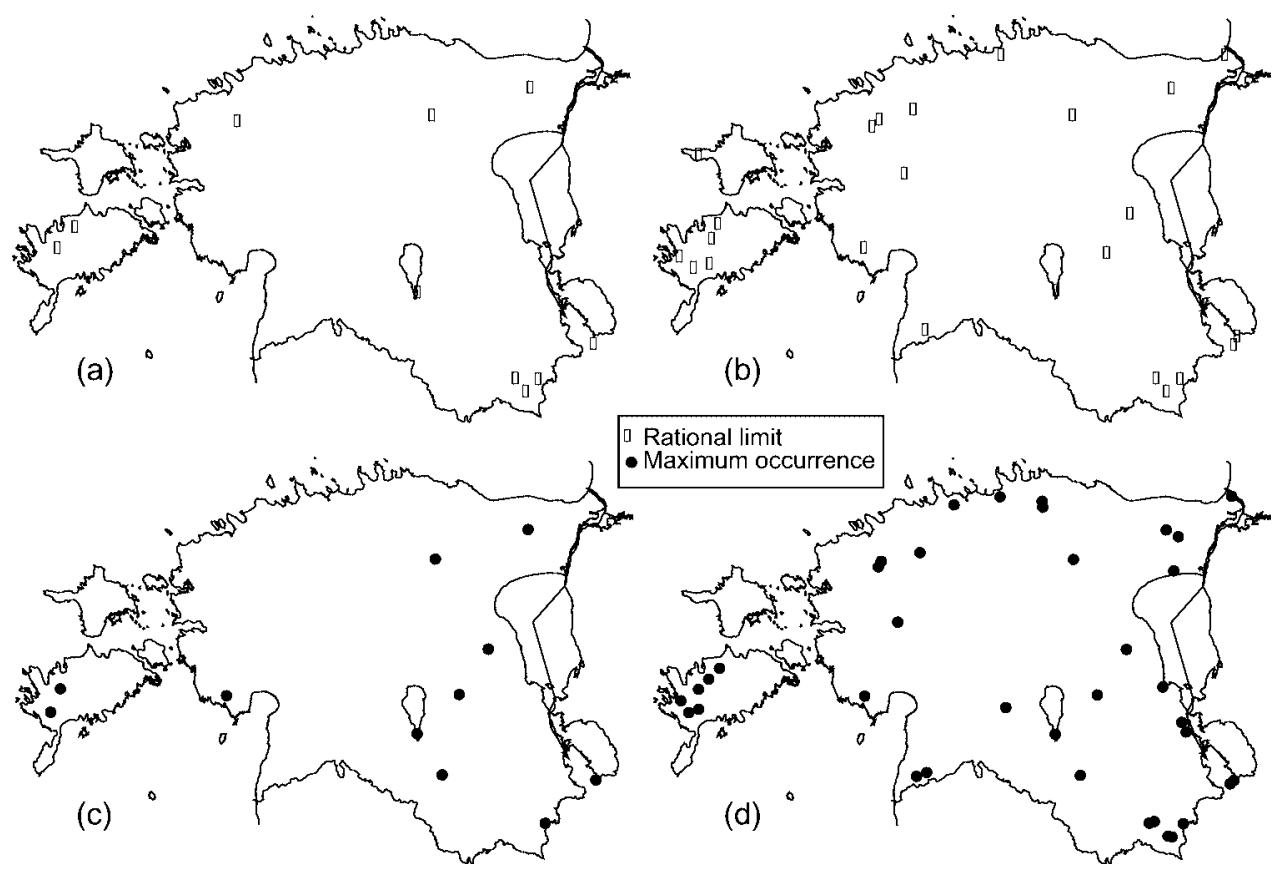

Fig. 5. Maps showing the distribution of Quercus pollen at different times. (a) the rational limit between 7500 and $7000 \mathrm{BP}$, (b) the rational limit between 6500 and $6000 \mathrm{BP}$, (c) maximum occurrence between 5000 and $4500 \mathrm{BP}$, (d) maximum occurrence between 4000 and $3500 \mathrm{BP}$.

Carpinus. Occasional grains of Carpinus were recorded more often from $3000 \mathrm{BP}$ onwards. It forms a low, $0.3-0.6 \%$ continuous curve only on very few high-resolution pollen diagrams, such as Viitna, Vedruka, Maardu, Ermistu, and Raigastvere.

Fagus pollen was found only occasionally and it never formed a continuous pollen curve, e.g. surpassed the empirical limit. This does not exclude that single beech trees have grown natively in the western archipelago of Estonia.

\section{DISCUSSION}

Immigration and expansion of thermophilous elm, lime, ash, oak, and hornbeam has a certain succession, caused mostly by climate, edaphic demands, local environmental conditions and, to a lesser extent, by human interference. By $6000 \mathrm{BP}$ elm, lime, and oak had reached their present-day range limit or near to it (Birks 1990). Elm became locally established already at the end of the Pre-Boreal at southern, western, and northern sites (Vaskna 9300 BP, Viitna and Maardu 9200 BP, Mustjärv, Senno, Ermistu, and Raigastvere 9000 BP; Fig. 2a,b). The 
map of the rational limit of elm presented by us differs from those published earlier (Serebryannyi 1973; Huntley \& Birks 1983, p. 421). Climate amelioration and available habitats have substantiated such rapid immigration and spread of elm. Elm major maximum occurred before $5500 \mathrm{BP}$, when elm together with lime was the main forest-forming tree in broad-leaved stands on uplands, heights, and archipelago. Still, elm reached maximum occurrence first in South Estonia and Saaremaa (Fig. 2c). Elm pollen dropped from 5500 BP onwards. This is interpreted as elm decline, not definitely caused by human activities, but could be a pathogenic attack as well (Peglar 1993; Greig 1996). At several sites elm decline is associated with diminished frequency of lime, followed by new recovery and new declines, showing that clearances were local and not regional. The scattered increase in elm representation c. 2000-1000 BP (sites 17, 29, 37, $41,47)$ could be the result of increased pollen dispersal in more open landscape.

The rapid and dispersed spread of elm is in contrast with the timetransgressive spread of lime in Estonia. The quite obvious northwestern immigration route for lime can be confirmed (Fig. 4a,b,c), which slightly differs from that suggested by Serebryannyi (1973), but coincides well with the map presented by Huntley \& Birks (1983). Even today lime extends farther to the east than most of the deciduous forest species on the territory of the former Soviet Union (Peterson 1983). At about 8500 BP lime colonized the southeast and reached the northwestern coastal area at about 7200-7000 BP (Fig. 4c), which makes the approximate range rate of $160 \mathrm{~m} \mathrm{yr}^{-1}$. This is 2-3 times slower than the average for the European mainland (Huntley \& Birks 1983). The maximum distribution of lime pollen before $6000 \mathrm{BP}$ (Fig. 4d) resembles its immigration pattern (Fig. 4a), culminating earlier in East and later in Northwest Estonia. Taking into account the correction for productivity and dispersal (Andersen 1970), elm-dominated woods have grown mostly before 7000 BP. At 7000 BP the proportions of elm and lime woods were almost equal, after that lime dominated in the broad-leaved forest everywhere in Estonia. The corrected pollen values show that lime could have made up to $30 \%$ of the total tree cover. Lime survived longest, for about 4000 years, on the Haanja Heights (Ilves \& Mäemets 1987; Saarse \& Rajamäe 1997). At several sites the lime decline is coherent with that of elm, at others it is registered several hundred years later. A noticeable reduction in lime pollen occurred after $4000 \mathrm{BP}$, and by $1000 \mathrm{BP}$ it had disappeared from several examined sites. Natural lime stands are today locally present in the northeastern and southern regions of Estonia (Paves 1974), single lime trees are growing in the foreklint forest and on the archipelago.

According to Huntley \& Birks (1983), oak immigrated into our territory from the southwest, which is hard to prove based on the Estonian material only (Fig. 5a). Maps for the whole of Europe show that oak spread progressively northward to reach its maximum range limit by $6000 \mathrm{BP}$ (Birks 1990). Considerable variation site by site is recorded in the timing of the empirical and rational limits of oak in Estonia (Figs. 3, 5a,b). According to new pollen records (Saarse et al. 1997; 
Veski 1998; Poska \& Saarse 1999), oak reached the northern coastal areas of Estonia at about 6000 BP. It took 3200 years for oak to reach the empirical limit and 4100 years to surpass the rational limit at all the examined sites (Fig. 3). Between 4000 and 3500 BP oak population expanded while the other broadleaved trees declined. The earlier maximum frequencies of oak in the southern and eastern profiles (Fig. 5c), and the late maximum frequencies in the northwestern profiles could be explained by differences in climatic conditions, which were more continental in the southeast and more maritime in northern and northwestern coastal regions of Estonia. Besides climate, a series of local factors, such as the topography, hydrology, soils, and conditions influencing seedling also determined the distribution of oak, as well as the other thermophilous taxa.

So, the broad-leaved forest started to spread into Estonia already in the PreBoreal and at its maximum between 6500 and $5000 \mathrm{BP}$ was represented by lime, elm, ash, and oak. Hornbeam appeared in the broad-leaved forest mostly from 3000 BP. Valk (1974), who gave the most comprehensive overview of the Estonian forest history, questioned the arrival and spread of elm in the PreBoreal. According to him, elm, if ever, could have been present with sparse stands, but it spread mostly in the Boreal. New high-resolution pollen diagrams confirm that elm was present in our forest in the second half of the Pre-Boreal (Ilves \& Mäemets 1987; Pirrus et al. 1987b; Veski 1998; Poska \& Saarse 1999).

\section{CONCLUSIONS}

The early and middle Holocene is characterized by successive arrival and expansion of broad-leaved trees in Estonia. Comparison of the immigration and expansion of elm, lime, and oak manifests their different response to climate, edaphic conditions, and competition. Elm is most widely distributed in the Boreal and the early Atlantic, lime in the Atlantic, and oak in the Sub-Boreal. Elm showed a very rapid colonization and became abundant almost simultaneously in different regions of Estonia, whereas lime immigrated and reached its maximum first in southern and eastern areas. At the more western sites the immigration and culmination of lime delayed for about 500 years. Elm prevailed in forests as a dominant broad-leaved taxon up to $7000 \mathrm{BP}$ when Ulmus-dominated forests occupied extensive areas on the uplands, heights, and islands. By $7000 \mathrm{BP}$ elm and lime forests were more or less evenly represented. After that lime became the most abundant broad-leaved taxon forming up to $30 \%$ of the total forest area and the high representation of lime lasted locally up to $4000 \mathrm{BP}$. The regional broadleaved forest reached its maximum density between 6500 and 4500 when the peak of Quercetum mixtum consisted mostly of lime, elm, oak, and ash, with some hornbeam. The gradual retreat of broad-leaved forest started with the decline of elm at about 5500-5000 BP, which was quite asynchronous in Estonia, being caused, most probably, by the combination of climate deterioration, anthropogenic forest clearances, and fungal diseases. 


\section{ACKNOWLEDGEMENTS}

The authors are grateful to A. Raukas for critical reading and improvement of the manuscript. The research was supported by grant No. 3621 of the Estonian Science Foundation and by governmental research grant 0330358 s 98 .

\section{REFERENCES}

Andersen, S.-Th. 1970. The relative pollen productivity and representation of north European taxa, and correction for tree pollen spectra. Dan. geol. Unders., series 2, 96.

Birks, H. J. B. 1989. Holocene isochrone maps and patterns of tree-spreading in the British Isles. J. Biogeogr., 16, 503-540.

Birks, H. J. B. 1990. Changes in vegetation and climate during the Holocene of Europe. In Landscape-Ecological Impact of Climatic Change (Boer, M. M. \& Groot, R. S., eds.), pp. 133-158. IOS Press, Amsterdam.

Davis, M. B. \& Sugita, S. 1997. Reinterpretation of the fossil pollen record of Holocene tree migration. In Past and Future Rapid Environmental Changes: the Spatial and Evolutionary Responses to Terrestrial Biota (Huntley, B., Cramer, W., Morgan, A. V., Prentice, H. C. \& Allen, J. R. M., eds.). NATO ASI Series, 1, 181-193.

Greig, J. 1996. Great Britain-England. In Palaeoecological Events During the Last 15000 Years. Regional Syntheses of Palaeoecological Studies of Lakes and Mires in Europe (Berglund, B. E., Birks, H. J. B., Ralska-Jasiewiczowa, M. \& Wright, H. E., eds.), pp. 1576. Wiley, Chichester.

Hansson, A.-M., Hiie, S., Kihno, K., Masauskaite, R., Moe, D., Seiriene, V. \& Torske, N. 1996. A vegetation historical study of Jõhvikasoo, an ombrotrophic mire at Tuiu, Saaremaa, Estonia. PACT, 51, 39-55.

Hultén, E. 1950. Atlas över växternas utbredning i Norden. Generalstabens Litografiska Anstalts Förlag, Stockholm.

Huntley, B. 1988. Glacial and Holocene vegetation history: Europe. In Vegetation History (Huntley, B. \& Webb, T. III, eds.), pp. 341-383. Kluwer, Dordrecht.

Huntley, B. \& Birks, H. J. B. 1983. An Atlas of Past and Present Pollen Maps for Europe 0-13000 Years Ago. Cambridge Univ. Pr.

Ilves, E. 1980. Tartu radiocarbon dates. Radiocarbon, 22, 1084-1089.

Ilves, E. \& Mäemets, H. 1987. Results of radiocarbon and palynological analyses of coastal deposits of lakes Tuuljärv and Vaskna. In Palaeohydrology of the Temperate Zone III. Mires and Lakes (Raukas, A. \& Saarse, L., eds.), pp. 108-130. Valgus, Tallinn.

Ilves, E., Männil, R. \& Valk, U. 1967. Jääajajärgsete metsade arenemisfaaside vanuse määramine radioaktiivse süsiniku meetodil Kuiksilla soos. Metsanduslikud uurimused V (Rebane, H., ed.), pp. 235-244. Valgus, Tallinn.

Ilves, E. \& Sarv, A. 1969. Die Stratigraphie und Chronologie der organischen Ablagerungen im Hochmoor Kalina. ENSV TA Toim. Keemia Geol., 18, 377-384 (in Russian).

Ilves, E. \& Sarv, A. 1970. Stratigraphie und Chronologie der See- und Torfablagerungen des Moores Ulila (Mittel-Estland). ENSV TA Toim. Keemia Geol., 19, 135-140 (in Russian).

Ilves, E., Sarv, A. \& Valk, U. 1968. C ${ }^{14}$-Datierungen zur Entwicklungsgeschichte der Wälder nach Materialien aus dem Hochmoor Teosaare (Estnische SSR). ENSV TA Toim. Keemia Geol., 17, 53-58 (in Russian).

Kaar, E. 1972a. Saar ja saarikud Eestis. Eesti Loodus, 3, 138-144. 
Kaar, E. 1972b. Tammemetsad Eestis. Eesti Loodus, 9, 527-531.

Kaar, E. 1974. Kõvad lehtpuud. In Eesti metsad (Valk, U. \& Eilart, J., eds.), pp. 146-155. Valgus, Tallinn.

Kalda, A. 1972. Tammest ja tammikutest. Eesti Loodus, 9, 513-520.

Kimmel, K., Rajamäe, R. \& Sakson, M. 1996. The Holocene development of Tondi Mire, northern Estonia: pollen, diatom and chronological studies. PACT, 51, 85-102.

Kimmel, K., Pirrus, R. \& Raukas, A. 1999. Holocene deposits. In Lake Peipsi: Geology (Miidel, A. \& Raukas, A., eds.), pp. 42-52. Sulemees Publishers, Tallinn.

Koff, T. 1984. On the possibilities of the formation of pollen spectra in mire and lake sediments (on the example of Viitna district, North Estonia). In Khronologiya $i$ formirovanie chetvertichnogo pokrova Éstonii (Raukas, A., ed.), pp. 37-50. Inst. geol., Akad. nauk ESSR, Tallinn (in Russian).

Koff, T. 1994. The development of vegetation. In The Influence of Natural and Anthropogenic Factors on the Development of Landscapes (Punning, J.-M., ed.), pp. 24-57. Inst. Ecol., Estonian Acad. Sci.

Königsson, L.-K. \& Poska, A. 1998. Pitkasoo - a West Estonian Holocene reference site. Proc. Estonian Acad. Sci. Geol., 47, 242-261.

Königsson, L.-K., Saarse, L. \& Veski, S. 1998. Holocene history of vegetation and landscape on the Kõpu Peninsula, Hiiumaa Island, Estonia. Proc. Estonian Acad. Sci. Geol., 47, 3-19.

Kullmann, L. 1998. Non-analogous tree flora in the Scandes Mountains, Sweden, during the early Holocene macrofossil evidence of rapid geographic spread and response to palaeoclimate. Boreas, 27, 153-161.

Külvik, M. 1996. Status of biological resources. In Estonian Environment: Past, Present and Future (Raukas, A. ed.), pp. 36-40. Ministry of the Environment of Estonia, Environment Information Centre, Tallinn.

Lepland, A., Hang, T., Kihno, K., Sakson, M., Sandgren, P. \& Lepland, A. 1996. Sea-level changes and environmental history in the Narva area, north-eastern Estonia. PACT, 51, 313-358.

Miidel, A., Hang, T., Pirrus, R. \& Liiva, A. 1995. On the development of the southern part of Lake Peipsi in the Holocene. Proc. Estonian Acad. Sci. Geol., 44, 33-44.

Moora, T., Ilomets, M. \& Jaanits, L. 1988. Muistsetest loodusoludest Akali kiviaja asulakoha lähiümbruses. In Loodusteaduslikke meetodeid Eesti arheoloogias (Rõuk, A.-M. \& Jaanits, L., eds.), pp. 26-38. Eesti NSV Tead. Akad. Ajaloo Inst., Tallinn.

Paves, H. 1974. Eesti metsades kasvavatest teistest kodumaistest puuliikidest. In Eesti metsad (Valk, U. \& Eilart, J., eds.), pp. 156-158. Valgus, Tallinn.

Peglar, S. M. 1993. The mid-Holocene Ulmus decline at Diss Mere, Norfolk, UK: a year-by-year pollen stratigraphy from annual laminations. The Holocene, 3, 1-13.

Peterson, G. M. 1983. Recent pollen spectra and zonal vegetation in the western USSR. Quat. Sci. Rev., 2, 281-321.

Pirrus, R., Rõuk, A.-M. \& Koff, T. 1987a. Geology and development of a kettle hole on the Laiuse drumlin (eastern Estonia). Proc. Estonian Acad. Sci. Geol., 36, 1-5 (in Russian).

Pirrus, R., Rõuk, A.-M. \& Liiva, A. 1987b. Geology and stratigraphy of the reference site of Lake Raigastvere in Saadjärv drumlin field. In Palaeohydrology of the Temperate Zone II. Lakes (Raukas, A. \& Saarse, L., eds.), pp. 101-122. Valgus, Tallinn.

Pirrus, R., Hang, T. \& Liiva, A. 1993. On the geological development of the Väike-Emajõgi valley and the southern part of Lake Võrtsjärv. Proc. Estonian Acad. Sci. Geol., 42, $28-37$ (in Russian).

Poska, A. 1994. Three Pollen Diagrams from Coastal Estonia. Kvartärgeologiska Avdelningen Uppsala Universitet. Licentiate thesis, 170. Uppsala-Tallinn.

Poska, A. \& Saarse, L. 1999. Holocene vegetation and land-use history in the environs of Lake Kahala, northern Estonia. Veget. Hist. Archaeobot., 3, 185-197. 
Poska, A. \& Saarse, L. 2001. Vegetation development and introduction of agriculture to Saaremaa Island, Estonia. The Holocene (submitted).

Punning, J.-M., Koff, T., Ilomets, M. \& Jõgi, J. 1995. The relative influence of local, extra-local, and regional factors on organic sedimentation in the Vällamäe kettle hole, Estonia. Boreas, 24, 65-80.

Rasmussen, K. L., Aaby, B. \& Gwozds, R. 2000. The age of the Kaali meteorite crater. Meteoritics Planet. Sci., 35, 1067-1071.

Saarse, L. 1994. Bottom Deposits of Small Estonian Lakes. Inst. Geol., Estonian Acad. Sci., Tallinn (in Russian).

Saarse, L. \& Königsson, L.-K. 1992. Holocene environmental changes on the Island of Saaremaa, Estonia. PACT, 37, 97-131.

Saarse, L. \& Liiva, A. 1995. Geology of the Äntu group of lakes. Proc. Estonian Acad. Sci. Geol., 44, 119-132.

Saarse, L. \& Rajamäe, R. 1997. Holocene vegetation and climatic change on the Haanja Heights, SE Estonia. Proc. Estonian Acad. Sci. Geol., 46, 75-92.

Saarse, L., Veski, S., Heinsalu, A., Rajamäe, R. \& Martma, T. 1995. Litho- and biostratigraphy of Lake Päidre, South Estonia. Proc. Estonian Acad. Sci. Geol., 44, 45-59.

Saarse, L., Mäemets, H., Pirrus, R., Rõuk, A.-M., Sarv, A. \& Ilves, E. 1996. Estonia. In Palaeoecological Events During the Last 15000 Years: Regional Syntheses of Palaeoecological Studies of Lakes and Mires in Europe (Berglund, B. E., Birks, H. J. B., RalskaJasiewiczowa, M. \& Wright, H. E., eds.), pp. 367-393. Wiley, Chichester.

Saarse, L., Heinsalu, A., Poska, A., Veski, S., Rajamäe, R., Kihno, K. \& Martma, T. 1997. Early Holocene shore displacement of the Baltic Sea east of Tallinn (N Estonia). Baltica, 10, 13-24.

Saarse, L., Poska, A., Kaup, E. \& Heinsalu, A. 1998. Holocene environmental events in the Viitna area, North Estonia. Proc. Estonian Acad. Sci. Geol., 47, 31-44.

Saarse, L., Poska, A. \& Veski, S. 1999. Spread of Alnus and Picea in Estonia. Proc. Estonian Acad. Sci. Geol., 48, 170-186.

Sarv, A. 1983. Stratigraphical subdivision of the Holocene bog and lacustrine deposits of the Remmeski and Senno sections. In Palinologiya $v$ geologicheskikh issledovaniyakh Pribaltiki i Baltijskogo morya (Bartosh, T. D., ed.), pp. 77-83. Zinatne, Riga (in Russian).

Sarv, A. \& Ilves, E. 1971. Radiocarbon dating of bog-lacustrine deposits of the Vaharu bog (northwestern Estonia). In Palinologicheskie issledovaniya v Pribaltike (Bartosh, T. D., ed.), pp. 143-149. Zinatne, Riga (in Russian).

Sarv, A. \& Ilves, E. 1975. Über das Alter der holozänen Ablagerungen im Mündungsgebiet des Flusses Emajõgi (Saviku). ENSV TA Toim. Keemia Geol., 24, 64-69 (in Russian).

Sarv, A. \& Ilves, E. 1976. Geochronological subdivision of Holocene bog-lacustrine deposits in south-western Estonia. In Palinologicheskie issledovaniya $v$ izuchenii kontinental'nykh $i$ donnykh otlozhenij Pribaltiki i Baltijskogo morya (Bartosh, T. D., ed.), pp. 47-59. Zinatne, Riga (in Russian).

Serebryannyi, L. R. 1973. Postglacial distribution of trees in the north-western USSR. In Geologiya golotsena i marinopalinologiya (Khotinskij, N. A. \& Koreneva, E. V., eds.), pp. 14-18. Nauka, Moscow (in Russian).

Tallantire, P. A. 1972. Spread of spruce (Picea abies (L.) Karst.) in Fennoscandia and possible climatic implications. Nature, 236, 64-65.

Valk, U. 1974. Eesti metsade arengulugu. In Eesti metsad (Valk, U. \& Eilart, J., eds.), pp. 31-40. Valgus, Tallinn.

Veski, S. 1998. Vegetation history, human impact and palaeogeography of West Estonia. Pollen analytical studies of lake and bog sediments. STRIAE, $\mathbf{3 8}$. 


\section{LAIALEHISTE PUUDE LEVIK EESTIS}

\section{Leili SAARSE ja Siim VESKI}

On käsitletud jalaka/künnapuu, pärna, tamme, saare ja valgepöögi sisserännet ning levikut Eestis 46 radiosüsiniku meetodil dateeritud palünoloogilise diagrammi põhjal. Jalaka ja tamme sisserände alguseks on peetud aega, kui nende õietolmu hulk hakkas kiiresti tõusma (nn. ratsionaalne piir). Pärna, saare ja valgepöögi puhul on selleks kriteeriumiks nn. empiiriline piir, s.o. aeg, kui nende õietolmu sisaldus moodustab pideva kõvera. Jalaka, pärna ja saare sisserände ja levimise iseloomustamiseks on koostatud õietolmu leviku kaardid 500-aastase intervalliga. Palünoloogilise andmestiku analüüs näitab, et jalakas jõudis Eestisse preboreaali teisel poolel ja u. 9000 a.t. oli levinud kõikjal üle Eesti. Jalaka õietolmu maksimum jääb ajavahemikku $7900-4300$ a.t. Jalakas hakkas meie metsadest taanduma atlantikumi lõpul. Selle põhjuseks oli ilmselt nii kliima halvenemine, metsade raadamine kui ka jalakametsi kahjustanud haigused. Pärn tuli Eestisse lõuna ja ida poolt peamiselt boreaalis ning jõudis Loode-Eestisse u. 7000 a.t. See annab keskmiseks levikukiiruseks $160 \mathrm{~m} / \mathrm{a}$. Boreaali teisel poolel hakkas meil levima ka tamm, kuid võrreldes jalaka ja pärnaga aeglaselt. Nii jõudis tamm maksimumi alles 4200-3100 a.t. Koos tammega esineb saart, kuid tema osakaal on läbi aegade olnud küllaltki väike. Kõige hiljem, u. 3000 a.t., jõudis meie alale valgepöök, levides väga tagasihoidlikult Lääne-Eestis ja saartel. Võttes arvesse õietolmu produktsiooni erinevust on järeldatud, et 8000-7000 a.t. oli laialehistes metsades dominandiks jalakas, 7000 a.t. oli jalaka hulk enamvähem võrdne pärna omaga, 7000-4000 a.t. on aga pärn olnud selges ülekaalus, 4000-3000 a.t. seevastu tamm. Kõik nimetatud laialehised puud jäävad meil oma levikuareaali põhja piirile, mistõttu laialehiste puude osakaal, mis atlantikumi teisel poolel võis ulatuda 30-40\%-ni on langenud 1\%-ni.

\section{РАСПРОСТРАНЕНИЕ ШИРОКОЛИСТВЕННЫХ ПОРОД В ЭСТОНИИ}

\section{Лейли СААРСЕ и Сийм ВЕСКИ}

Представлены данные об иммиграции в Эстонию и распространении по ее территории вяза, липы, дуба, ясеня и граба в виде 46 палинологических диаграмм, составленных по радиоуглеродным датировкам находок. Начало иммиграции вяза и дуба фиксировалось временем, когда пыльцевые показатели этих пород значительно возрастали (т. н. рациональная граница). В случае липы, ясеня и граба за иммиграционный критерий принималось время, когда содержание пыльцы отображалось в виде непрерывной кривой 
(т. н. эмпирическая граница). Для иллюстрации распространения вяза, липы и дуба составлены карты с интервалом в 500 лет. Анализ палинологического материала показывает, что вяз появился в Эстонии во второй половине пребореала и в течение 500 лет, или к концу пребореала, произрастал по всей ее территории. Максимум пыльцы вяза приходится на интервал 7900-4300 лет назад. Вязовые леса значительно поредели в конце атлантической фазы по причине, видимо, ухудшения климатических условий, выкорчевки деревьев в связи с переходом на подсечное земледелие, а также из-за болезней. Липа иммигрировала в Эстонию с юга и востока в бореале и достигла северо-запада примерно 7000 лет назад, продвигаясь в среднем на 160 м в год. Во второй половине бореала появился в Эстонии и дуб, но его распространение по сравнению с вязом и липой шло медленнее. Так, его максимум на кривой находится в интервале 4200-3100 лет назад. Вместе с дубом иммигрировал и ясень, но его удельный вес в течение всего голоцена был довольно скромным. Граб проник на территорию Эстонии позже других пород и около 3000 лет назад занял небольшие площади на островах и в западной части материка. Учитывая разницу в продукции пыльцы рассмотренными породами, сделан вывод, что 8000-7000 лет назад в широколиственных лесах доминировал вяз, 7000-4000 лет назад - липа, 4000-3000 лет назад - дуб. Все эти породы произрастают сейчас на северной границе их ареала и занимают не более $1 \%$ площади против $30-40 \%$ во второй половине атлантики. 